\title{
Punggung Sehat dengan Mckenzie Back Exercises Selama Pembelajaran Daring bagi Mahasiswa STIKes Hang Tuah Tanjungpinang
}

\author{
Yusnaini Siagian', Soni Hendra Sitindaon ${ }^{2}$ \\ ${ }^{1,2}$ Prodi Profesi Ners STIKes Hang Tuah Tanjungpinang \\ Email:nersyusie81@stikesht-tpi.com
}

Submitted : 24/09/2021

Accepted: 16/10/2021

Published: 19/11/2021

\begin{abstract}
Low back pain is pain that originates from the spine in the spinal area, muscles, nerves, tendons, joints, or cartilage due to the wrong position. Individuals who perform activities such as sitting up straight and bending over must be in the correct position. At Stikes Hang Tuah Tanjungpinang, a phenomenon was found that $42.7 \%$ of students complained of lower back pain due to wrong sitting habits such as sitting in a bent position when attending online lectures and doing college assignments. Sitting for too long in the wrong position causes muscle tension and spinal ligament strain. The results of interviews with students, most of the students who complain of low back pain do not understand what can be done to reduce or prevent low back pain due to sitting position and sitting too long. One of the non-pharmacological therapies to treat low back pain is McKenzie back exercises. The purpose of this community service is to provide students with an understanding of low back pain and teach actions to reduce or prevent low back pain. The success indicator of this activity is that students understand and can perform the McKenzie back exercises The method used is to provide health education about low back pain and demonstrate McKenzie back exercises to students.
\end{abstract}

Keywords: health education, mckenzie back exercise, students low back pain

\begin{abstract}
Abstrak
Nyeri punggung bawah merupakan rasa nyeri yang bersumber dari tulang belakang daerah spinal, otot, saraf, tendon, sendi, atau kartilago akibat posisi yang salah. Seseorang pada saat melakukan aktivitas seperti duduk tegak dan posisi membungkuk harus dilakukan dengan posisi yang benar. Fenomena yang terjadi pada mahasiswa Stikes Hang Tuah Tanjungpinang didapatkan data 42,7 \% mahasiswa mengeluh nyeri punggung bawah karena kebiasaan duduk yang salah seperti duduk dengan posisi membungkuk saat mengikuti perkuliahan daring dan mengerjakan tugas kuliah. Terlalu lama posisi duduk dengan posisi yang salah menyebabkan ketegangan otot-otot dan keregangan ligamentum tulang belakang. Hasil wawancara terhadap mahasiswa hampir sebagian besar mahasiswa yang mengeluh nyeri punggung bawah belum memahami tentang hal yang dapat dilakukan untuk mengurangi atau mencegah nyeri punggung bawah akibat posisi duduk dan lama duduk terlalu lama. Terapi non farmakologi untuk mengatasi nyeri punggung bawah salah satunya dengan McKenzie back exercises. Tujuan pengabdian kepada masyarakat ini adalah memberikan pemahaman bagi mahasiswa tentang nyeri punggung bawah dan mengajarkan tindakan mengurangi maupun mencegah terjadinya nyeri punggung bawah. Metode yang digunakan dengan memberikan pendidikan kesehatan tentang nyeri punggung bawah dan mendemonstrasikan McKenzie back exercises pada mahasiswa. Indikator keberhasilan dari kegiatan ini adalah mahasiswa memahami dan dapat melakukan teknik McKenzie back exercises. Pengabdian kepada masyarakat ini dilakukan di Stikes Hang Tuah Tanjungpinang pada bulan April sampai dengan Mei 2021. Hasil kegiatan ini seluruh mahasiswa yang hadir memahami dan dapat melakukan McKenzie back exercises.
\end{abstract}

Kata Kunci: nyeri punggung bawah, mckenzie back exercises, pendidikan kesehatan, mahasiswa

PENDAHULUAN

Pembelajaran daring, online atau Pembelajaran Jarak Jauh sendiri bertujuan untuk memenuhi standart pendidikan dengan pemanfaatan teknologi informasi dengan menggunakan 
perangkat komputer atau gadget yang saling terhubung antara siswa dan guru maupun antara mahasiswa dengan dosen sehingga melalui pemanfaatan teknologi tersebut proses belajar mengajar bisa tetap dilaksanakan dengan baik.

Posisi tubuh yang salah dan duduk terlalu lama saat kuliah dan belajar merupakan salah satu faktor risiko terjadi nyeri punggung bawah. Lamanya jumlah jam kuliah yang harus diikuti mahasiswa mengakibatkan aktivitas mahasiswa lebih banyak dihabiskan dengan duduk saat mengikuti proses perkuliahan termasuk pada mahasiswa di Stikes Hang Tuah Tanjungpinang. Perkuliahan daring akibat dari pandemic Covid19 ini, memungkinkan ketidaknyamanan mahasiswa pada saat perkuliahan semakin meningkat. Proses belajar yang lama antara 4 hingga 5 jam menjadikan mahasiswa mengalami banyak keluhan mulai dari stress, bagian tubuh tertentu sakit, tidak fokus, dan lain-lain.

Nyeri punggung bawah merupakan rasa nyeri yang bersumber dari tulang belakang daerah spinal, otot, saraf, tendon, sendi, atau kartilago (Riningrum dan Widowati, 2016). Beberapa faktor risiko terkait dengan kejadian nyeri punggung bawah yaitu faktor individu, faktor pekerjaan dan lingkungan (Allegri dkk, 2016). Faktor individu banyak didapatkan pada kejadian nyeri punggung bawah kronik yang banyak terjadi pada usia diatas 30 tahun (Hochschuler, S. H. 2018).

Berdasarkan data RISKESDAS tahun 2013, prevalensi penyakit muskuloskeletal di Indonesia berdasarkan pernah di diagnosis oleh tenaga kesehatan yaitu $11,9 \%$ dan berdasarkan diagnosis atau gejala yaitu $24,7 \%$. Jumlah penderita nyeri punggung bawah di Indonesia tidak diketahui secara pasti, namun diperkirakan antara $7,6 \%$ sampai $37 \%$.

Kejadian nyeri punggung bawah pada usia kurang dari 30 tahun banyak disebabkan oleh faktor pekerjaan. Beban otot statik dan fleksi tulang belakang lumbar telah terbukti merupakan faktor resiko dari kejadian nyeri punggung belakang, sehingga duduk lama dalam posisi yang tidak normal dapat memperburuk nyeri punggung yang merupakan salah satu faktor pekerjaan (Hochschuler, 2018).

Posisi tubuh yang salah dan duduk terlalu lama saat kuliah dan belajar merupakan salah satu faktor risiko nyeri punggung bawah. Lamanya jumlah jam kuliah yang harus diikuti mahasiswa mengakibatkan aktivitas mahasiswa lebih banyak dihabiskan dengan duduk saat mengikuti proses perkuliahan daring termasuk pada mahasiswa di Stikes Hang Tuah Tanjungpinang.

Hasil studi pendahuluan di Stikes Hang Tuah Tanjungpinang, jadwal kuliah rata-rata 4-5 jam untuk Program Studi D3 Keperawatan, S1 Keperawatan dan Profesi Ners. Jadwal kuliah daring mahasiswa reguler secara umum dimulai dari jam 8 pagi sampai dengan jam 3 sore. Selama proses perkuliahan diberikan waktu istirahat selama 1 jam yaitu dari jam 12.00 wib sampai dengan jam 13.00 wib, kemudian perkuliahan dilanjutkan kembali sampai dengan jam 3 bahkan sampai sore jika ada perubahan jadwal dari dosen pengajar. Dari gambaran diatas jelas terlihat bahwa sebagian besar aktivitas mahasiswa dihabiskan dengan posisi duduk yang lama saat kuliah daring berlangsung, dimana untuk 1 mata kuliah mahasiswa harus duduk selama 2-3 jam. Selain itu mahasiswa juga harus mengerjakan tugas kuliah yang diberikan dosen pengajar yang dikerjakan diluar dari jam perkuliahan. Hal ini menjadi faktor risiko terjadinya nyeri punggung bawah pada mahasiswa saat perkuliahan karena terlalu lama duduk dengan posisi yang salah.

Hasil wawancara terhadap mahasiswa baik D3 Keperawatan, S1 Keperawatan maupun Profesi Ners hampir sebagian besar mahasiswa Stikes Hang Tuah Tanjungpinang sejak diberlakukannya 
metode pembelajaran daring mengatakan mengalami keluhan fisik terutama nyeri punggung bawah. Mahasiswa yang mempunyai keluhan nyeri punggung bawah mayoritas belum memahami tentang nyeri punggung bawah, hal yang dapat dilakukan untuk mengurangi, mengatasi bahkan mencegah nyeri punggung bawah.

Hasil penelitian Navariastami Nanin, dkk (2015) menyatakan McKenzie back exercises dapat menghilangkan nyeri punggung bawah, mengurangi kekakuan, mengembalikan elastisitas sehingga bisa mencapai mobilitas penuh dan meningkatkan status kesehatan. Berdasarkan data diatas maka perlu dilakukan pemberian pendidikan kesehatan tentang nyeri punggung bawah dan cara melakukan McKenzie back exercises untuk mengatasi nyeri punggung bawah pada Mahasiswa Stikes Hang Tuah Tanjungpinang.

\section{TARGET DAN LUARAN}

Sehubungan dengan permasalahan yang dialami oleh mitra maka analisis tim pengabdian kepada masyarakat dengan mitra yaitu Ketua Stikes Hang Tuah Tanjungpinang mengadakan kegiatan sebagai berikut : "memberikan pendidikan kesehatan tentang nyeri punggung bawah dengan menghadirkan mahasiswa selanjutnya memberikan pemahaman tentang nyeri punggung bawah, penyebab terjadinya dan tindakan pencegahan maupun tindakan mengatasi serta pencegahan terjadinya keluhan nyeri punggung bawah dengan Mckenzie back exercises. Media yang digunakan saat kegiatan adalah LCD, Laptop, Sound system. Selain kegiatan pendidikan kesehatan dilakukan demonstrasi cara mengatasi nyeri punggung bawah dengan Mckenzie back exercises.

Target secara umum dari kegiatan pengabdian kepada masyarakat ini adalah memberikan pemahaman bagi mahasiswa tentang nyeri punggung bawah dan melakukan tindakan mengurangi maupun mencegah terjadinya nyeri punggung bawah terutama untuk dirinya sendiri. Sedangkan target secara khusus dari kegiatan ini adalah Mahasiswa mampu memahami tentang nyeri punggung bawah akibat posisi duduk yang salah dan lama duduk selama pembelajaran daring, Mahasiswa mampu memahami dampak nyeri punggung bawah bagi kesehatannya dan Mahasiswa mampu mendemonstrasikan cara melakukan McKenzie back exercises untuk mengatasi nyeri punggung bawah.

\section{METODE PELAKSANAAN}

Kegiatan pengabdian masyarakat dikemas dalam bentuk pemberian pendidikan kesehatan tentang nyeri punggung bawah yang bertujuan untuk meningkatkan pengetahuan mahasiswa tentang nyeri punggung bawah. Sedangkan mengajarkan melakukan tehnik McKenzie back exercises bertujuan untuk meningkatkan keterampilan mahasiswa dalam mengatasi dan mencegah nyeri punggung bawah akibat lama duduk maupun posisi duduk yang tidak ergonomis. Kegiatan ini merupakan implementasi dari Tri Dharma Perguruan Tinggi. Metode yang digunakan adalah ceramah, diskusi, tanya jawab dan demonstrasi. Metode ceramah digunakan pada saat pemberian pendidikan kesehatan tentang nyeri punggung bawah dengan slide power point, sedangkan metode diskusi digunakan untuk mengetahui pemahaman mahasiswa tentang nyeri punggung bawah dan cara mengatasinya. Metode demonstasi digunakan saat mengajarkan tehnik McKenzie back exercises untuk mengatasi nyeri punggung bawah.

Alat dan media yang digunakan adalah LCD, Laptop dan Soundsystem. Pengabdian kepada masyarakat ini dilakukan bulan April sampai dengan bulan Mei 2021.

\section{HASIL DAN PEMBAHASAN}

Secara keseluruhan kegiatan pengabdian masyarakat ini berjalan dengan baik dan lancar. Seluruh mahasiswa yang hadir mengikuti rangkaian kegiatan dengan seksama dan antusias terbukti dengan 
interaksi yang konstruksif dari mahasiswa selama pelaksanaan kegiatan.

Kegiatan pengabdian kepada masyarakat telah dilaksanakan di Stikes Hang Tuah Tanjungpinang yang dihadiri oleh mahasiswa Stikes Hang Tuah Tanjungpinang. Setelah diberikan pendidikan kesehatan, diskusi dan tanya jawab kegiatan dilanjutkan dengan melakukan demonstrasi cara melakukan tehnik McKenzie back exercises. Hasil kegiatan pendidikan kesehatan tentang nyeri punggung bawah yang dilakukan terlihat mahasiswa sudah memahami apa yang disampaikan terbukti dengan kemampuan mahasiswa menjawab beberapa pertanyaan yang diberikan seputar materi nyeri punggung bawah. Mahasiswa juga mampu mengulang kembali gerakangerakan tehnik McKenzie back exercises yang sudah didemonstasikan. Bagi beberapa mahasiswa yang mempunyai keluhan nyeri punggung bawah menyatakan ada penurunan skala nyeri punggung bawah yang dirasakan setelah melakukan Mckenzie back exercises yang sudah diajarkan.

Menurut Notoatmodjo (2010) menyatakan pengetahuan adalah kesan dalam pikiran manusia sebagai hasil penggunaan panca indranya dan segala sesuatu apa yang diketahui bedasarkan pengalaman yang didapatkan oleh setiap manusia. Seseorang yang memiliki pengetahuan yang tinggi dalam sesuatu hal, akan mudah menerima perilaku yang lebih baik. Tingginya pengetahuan akan berdampak terhadap proses perubahan perilaku yang akan dilakukan sehubungan dengan permasalahan yang dihadapi.

Hasil pengabdian kepada masyarakat ini sejalan dengan hasil penelitian Putri, dkk (2018) yang menyatakan ada pengaruh yang signifikan antara latihan ekstensi McKenzie back exercises dengan penurunan tingkat nyeri punggung bawah dan hal ini didukung oleh hasil penelitian Satriadi AA, dkk (2018) yang menyatakan pemberian pelatihan peregangan dapat menurunkan tingkat nyeri punggung bawah. Peregangan otot jika dilakukan dengan benar dan teratur dapat mencegah dan membantu pemulihan nyeri punggung akibat posisi kerja yang salah, otot menegang akibat tidak bergerak dalam waktu yang lama, peredaran darah yang terhambat dan cedera ketegangan yang berulang. Nyeri punggung bawah jika tidak segera diatasi dapat menimbulkan efek lanjut seperti hernia nucleus pulposus dan kelumpuhan yang dapat mengganggu produktivitas. McKenzie back axercises salah satu terapi non farmakologi yang dapat dan mudah dilakukan untuk mengatasi nyeri punggung bawah tersebut.

Perlu kita pahami bersama bahwa nyeri punggung dapat merupakan akibat dan aktifitas kehidupan sehari-hari khususnya pekerjaan yang berkaitan dengan postur tubuh seperti pekerjaan yang membutuhkan duduk yang terus menerus. Aktivitas mahasiswa dengan posisi duduk yang lama saat kuliah berlangsung $>4$ jam dan tidak berubahubah dapat berisiko mengalami nyeri punggung bawah. Seseorang yang mengalami nyeri punggung bawah dapat menurunkan status kesehatannya. Melalui kegiatan ini diharapkan akan tercapai peningkatan status kesehatan mahasiswa dalam upaya pencegahan terjadinya nyeri punggung menjadi lebih buruk. Upaya pencegahan yang dimaksud meliputi peningkatan pengetahuan konsep nyeri punggung bawah, bahaya akibat nyeri punggung, dan cara melakukan McKenzie back exercises untuk mengatasi serta mencegah nyeri punggung bawah.

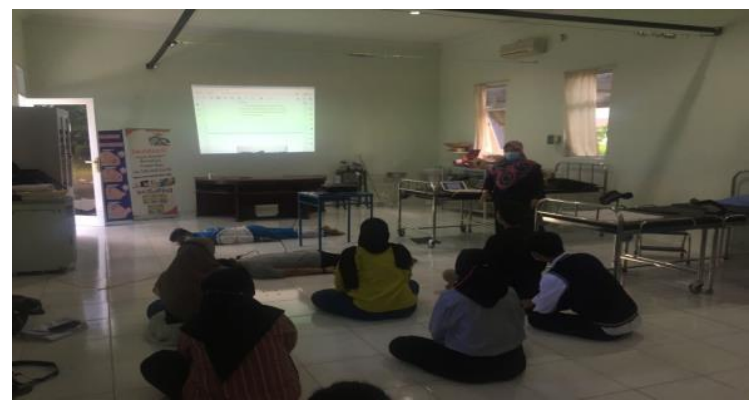

Gambar 1. Kegiatan Pendidikan Kesehatan 


\section{KESIMPULAN DAN SARAN}

\section{Kesimpulan}

Berdasarkan hasil pengabdian kepada masyarakat ini didapatkan data mahasiswa memahami dan dapat melakukan tindakan mengatasi nyeri punggung bawah dengan McKenzie back exercises, serta mengetahui waktu yang tepat untuk melakukan McKenzie back exercises. Selain itu gerakannya mudah dan dapat dilakukan secara mandiri. Seseorang yang mengalami nyeri punggung bawah dapat menurunkan status kesehatannya.

Melalui kegiatan ini diharapkan akan tercapai peningkatan status kesehatan mahasiswa dalam upaya pencegahan terjadinya nyeri punggung menjadi lebih buruk.

\section{Saran}

Mahasiswa Stikes Hang Tuah Tanjungpinang diharapkan selama melakukan aktivitas dengan duduk terutama mengikuti pembelajaran daring membiasakan posisi duduk yang benar, rajin berolahraga dan memberi waktu istirahat secara berkala jika sudah duduk lebih dari 2 jam. Mahasiswa juga harus memperhatikan hal yang dapat memperberat keluhan nyeri punggung bawah akibat lama duduk dan posisi duduk yang salah.

\section{UCAPAN TERIMAKASIH}

Terima kasih kepada Ketua Stikes Hang Tuah Tanjung pinang yang telah memfasilitasi dan memberikan dukungan dana kepada tim sehingga pengabdian kepada masyarakat ini dapat terlaksana dengan baik dan lancar.

\section{DAFTAR PUSTAKA}

Allegri, M., Montella, S., Salici, F., Valente, A., Marchesini, M., Compagone, C., Baciarello, M., Manferdini, M. E. dan Fanelli, G.. Mechanisms of low back pain: a guide for diagnosis and therapy. 2016 F1000Research. doi: 10.12688/f1000research.8105.2.

Hochschuler, S. H.( 2018). Back Pain Risk Factors: What Can Increase The Potential for Back Problems. Spine Health.

Kementerian Kesehatan RI. (2013). Riset kesehatan dasar (RISKESDAS). Badan Penelitian dan Pengembangan Kesehatan Kemenkes RI.

Navariastami Nanin, Hikayati, Nurna Ningsih. Pengaruh McKenzie Back Exercise terhadap Skala Nyeri Punggung Bawah Pengrajin Songket. Jurnal Skolastik Keperawatan. 2015;1(2).

Notoatmodjo S. (2010). Ilmu Perilaku Kesehatan. Jakarta, Rineka Cipta. 2040.

Riningrum, H. dan Widowati, E. Pengaruh Sikap Kerja, Usia, dan Masa Kerja Terhadap Keluhan Low Back Pain. Jurnal Pena Medika.

Satriadi, Albertus Are, Dkk. (2017). Pengaruh Peregangan Terhadap Keluhan Nyeri Punggung Bawah Pada Pekerja Bagian Produksi Di PT. SDJ Pontianak. Https://Jurnal.Untan.Ac.Id/Index.Ph p/Jfk/Article/Download/29455/75676 579045.

Putri, Ema dan T. Samsul Alam. ( 2018). Ergonomi Dalam Bekerja dengan Nyeri Punggung Bawah Pada Pekerja Buruh Kasar. JIM FKEP Universitas Syiah Kuala Banda Aceh.;3(3). 